\title{
Pengaruh Cahaya Terhadap Produksi Fukosantin Chaetoceros calcitrans (Paulsen) Takano 1968 (Bacillariophyceae: Chaetocerotaceae)
}

\author{
Sri Sedjati ${ }^{12 *}$, Endang Supriyantini ${ }^{1}$, Ali Ridlo', Ervia Yudiati ${ }^{1}$ dan \\ Linggar Dirgantara Prasetyo'
}

\author{
'Departemen Ilmu Kelautan, Fakultas Perikanan dan Ilmu Kelautan, Universitas Diponegoro \\ JI. Prof. Soedarto, SH. Kampus UNDIP Tembalang, Semarang 50275 \\ 2Marine Science Techno Park \\ Jl. Undip, Desa Teluk Awur, Tahunan, Jepara, Jawa Tengah 59427 \\ Email : sedjati69@gmail.com
}

\author{
Abstract \\ The Effect of Light on the Fucoxanthin Product of Chaetoceros calcitrans (Paulsen) Takano 1968 \\ (Bacillariophyceae; Chaetocerotaceae)
}

\begin{abstract}
Fucoxanthin is a pigment of the carotenoid group that can be used in the food and human health. The demand for natural carotenoid in the global market is quite high for food nutrition, food colorant, medicine, and cosmetic. Chaetoceros calcitrans included sea diatom rich in carotenoid, mainly fucoxanthin. This research aim is to optimize C. calcitrans cultivation using different light intensity treatment to create high fucoxanthin quantity. Light intensity treatment consisted of 4 levels : 1.000, 1.500, 2.000, and $2.500 \mathrm{~lx}$ with 2 replications. The culture process was done in mediumscale $(60 \mathrm{~L})$ for 14 days, enriched with diatom's fertilizer, vitamin B, silica at temperature $25-27^{\circ} \mathrm{C}$, salinity 32-33\%, $\mathrm{pH} 8-8,5$, and DO 7-9 $\mathrm{mg} / \mathrm{g}$. Biomass and pigments were harvested in stationer phase, two days after the peak of logarithmic growth. Pigments analysis used Spektrofotometry method, absorbance values were measured in wavelengths 445, 632, 649, 663, 665, and $696 \mathrm{~nm}$. The results showed that light intensity treatment was not significant in biomass weight $(p=0,06)$, but it is very significant to cells density $(p=0,01)$ and fucoxanthin production $(p=0,01)$. In conclusion, the light intensity of $2.500 \mathrm{~lx}$ was effective to obtain the highest fucoxanthin at the amount of 10,13 $\pm 1,62 \mathrm{mg} \mathrm{dw}$ with productivity at $0,17 \pm 0,03 \mathrm{mg} / \mathrm{g}$ culture media. The increase of light intensity correlated positively with the increase of fucoxanthin production with regression equation $y=$ $0,006 x-4,938(r=0,96)$. The increase in light intensity reaching $2500 \mathrm{~lx}$ in Chaetoceros calcitrans culture is proven can accelerate fucoxanthin biosynthesis, therefore the method can be applied to increase its production.
\end{abstract}

Keywords : Light intensity; production; stationer phase; fucoxanthin

\begin{abstract}
Abstrak
Fukosantin merupakan salah satu karotenoid yang bermanfaat dalam bidang pangan dan kesehatan manusia. Permintaan karotenoid alami di pasar global besar sekali untuk berbagai kegunaan dalam bidang nutrisi makanan, pewarna makanan, obat-obatan, dan kosmetik. Chaetoceros calcitrans termasuk diatom laut yang kaya karotenoid, terutama fukosantin. Penelitian ini bertujuan untuk mengoptimasi kultur $C$. calcitrans dengan menggunakan perlakuan intensitas cahaya berbeda agar memproduksi fukosantin yang tinggi. Perlakuan intensitas cahaya terdiri dari 4 taraf : 1.000, 1.500, 2.000, dan 2.500 Ix dengan 2 kali ulangan. Kultur dilakukan dalam skala medium $(60 \mathrm{~L})$ selama 14 hari, diperkaya dengan pupuk diatom, vitamin B, silikat pada suhu $25-27 \circ \mathrm{C}$, salinitas 32-33\%。, $\mathrm{pH} 8-8,5$, dan DO $7-9 \mathrm{mg} / \mathrm{g}$. Pemanenan biomassa dilakukan saat fase stasioner, yaitu 2 hari setelah puncak logaritmik. Analisis pigmen menggunakan metode Spektrofotometri, nilai absorbansi diukur pada panjang gelombang 445, 632, 649, 663, 665, dan 696
\end{abstract}


$\mathrm{nm}$. Hasil penelitian membuktikan bahwa perlakuan intensitas cahaya tidak berpengaruh nyata $(p=0,06)$ terhadap berat biomassa, tetapi sangat berpengaruh nyata terhadap kepadatan sel $(p=0,01)$ dan produksi fukosantin $(p=0,01)$. Pemberian intensitas cahaya $2.500 \mathrm{~lx}$ menghasilkan produksi fukosantin tertinggi, yaitu sebesar $10,13 \pm 1,62 \mathrm{mg} d w$ dengan produktivitas sebesar $0,17 \pm 0,03 \mathrm{mg} / \mathrm{g}$ media kultur. Kenaikan intensitas cahaya berkorelasi positif dengan kenaikan produksi fukosantin dengan persamaan regresi $y=0,006 x-4,938(r=0,96)$. Peningkatan intensitas cahaya sampai 2500 Ix pada kultur Chaetoceros calcitrans terbukti dapat memacu biosintesis fukosantin, sehingga metode tersebut bisa diaplikasikan untuk menaiknya produksinya.

Kata kunci : intensitas cahaya; produksi; fase stasioner; fukosantin

\section{PENDAHULUAN}

Mikroalgae merupakan sumber potensial penghasil nutrisi yang mudah diperbaharui karena pertumbuhannya cepat. Nutrisi ini bisa berbasis sebagai suplemen dalam bentuk biomassa maupun ekstrak murni yang mengandung asam lemak omega-3 dan karotenoid (Barkia dan Saari, 2019). Fukosantin adalah salah satu dari anggota keluarga karotenoid. Fukosantin banyak diteliti dan dieksplorasi karena memiliki beragam fungsi fisiologis dan biologis dalam bidang kesehatan, yaitu sebagai : antikanker (Kumar et al., 2013), antiradang (Heo et al., 2010), antiobesitas dan diabetes (Maeda et al., 2009), antibakteri (Renhoran et al., 2017), maupun antioksidan (Nursid et al., 2012; Foo et al., 2017; Azizan et al., 2018). Fukosantin adalah salah satu pigmen utama karotenoid laut, banyak ditemukan pada makroalgae maupun mikroalgae. Diatom adalah salah satu mikroalga kaya karotenoid, keistimewanya adalah kandungan fukosantinnya yang tinggi (Kim et al., 2012; Wang et al., 2018). Menurut Petrushkina et al., 2017, diatom merupakan sumber fukosantin potensial. Kandungannya bisa mencapai lebih dari $21.67 \mathrm{mg} / \mathrm{g}$ (berat kering/dry weight), sehingga menjadi daya tarik untuk dikembangkan secara intensif.

Kultur C. calcitrans bisa dilakukan di dalam sebuah fotobioreaktor yang diatur kondisi medianya, meliputi : suhu, intensitas cahaya dan penambahan nutrien (N, P, Si, dan vitamin B) (Krichnavaruk et al., 2005). Toleransi suhu bisa berada pada $20^{\circ}-30^{\circ} \mathrm{C}$ dan salinitas 25-35\% (Raghavan dan Haridevi, 2008). Intensitas pencahayaaan juga beragam kisarannya, 40-200 $\mathrm{mmol}$ foton $/ \mathrm{m}^{2} / \mathrm{s}$. Intensitas cahaya yang tinggi dapat meningkatkan pertumbuhan dan biomassanya (Zhang et al., 2017). Metabolit yang teridentifikasi dalam ekstraknya meliputi : 11 macam asam amino, 1 kolesterol, 6 asam lemak, 2 gula, 6 karotenoid (fukosantin, astasantin, kantasantin, lutein, zeasantin, violasantin) dan 2 klorofil (a dan $c_{1}$ ) (Azizan et al., 2018).

Optimalisasi kondisi lingkungan adalah suatu cara untuk meningkatkan produktivitas bimassa dan metabolit sel mikroalgae. Parameter yang berpengaruh meliputi : $\mathrm{pH}$, temperatur, cahaya, karbon dioksida, salinitas, dan nutrien (Gatamaneni et al., 2018). Intensitas cahaya merupakan salah satu faktor penentu kehidupannya. Intensitas cahaya biasa diukur dalam berbagai satuan: lux, foot-candles, maupun $\mu \mathrm{mol} \mathrm{m}^{2} / \mathrm{s}$. Masingmasing bisa saling dikonversikan dengan cara mengalikannya dengan faktor koreksi, sesuai jenis cahayanya. Cara konversi intensitas cahaya putih dari lampu (cool white fluorescent) dari lux ke $\mu \mathrm{mol} \mathrm{m}^{2} / \mathrm{s}$ yaitu mengalikannya dengan bilangan 0,0165 (Cycloptics, 2019). Beberapa penelitian sudah dilakukan dalam budidaya $C$. calcitrans menggunakan intensitas cahaya yang bervariasi. Mulai dari intensitas paling rendah, 16-40 $\mathrm{mmol} \mathrm{m} \mathrm{m}^{2} / \mathrm{s}$ atau 969,70-2.424,24 Ix (Kotako dan Powtongsook, 2006), 80-240 umol $\mathrm{m}^{2} / \mathrm{s}$ atau 4.848,49-14.545,45 Ix (Akbarnejad et al., 2017), $150 \mu \mathrm{mol} \mathrm{m} 2 / \mathrm{s}$ atau 9.090,91 Ix (Foo et al., 2015; Foo et al., 2017), bahkan sampai $500 \mu \mathrm{mol} \mathrm{m} / \mathrm{s}$ atau $30.303,03$ Ix (Raghavan \& Haridevi, 2008). Kesemua perlakuan dapat ditoleransi dan mikroalga dapat tumbuh, namun respon fisiologis dan biokimia berbeda-beda (kepadatan sel, biomasssa, dan metabolitnya.

Saat ini, optimalisasi kultur C. calsitrans digunakan untuk meningkatkan produksi biomassa yang kaya lipid sebagai pakan larva udang/ikan (Hemaiswarya et al., 2011; 
Chilmawati and Suminto, 2016), atau bahan baku biodiesel (Kwangdinata et al., 2014; Pemanfaatan C. calsitrans sebagai sumber fucosantin belum banyak dilakukan. Beberapa genus diatom sudah diteliti sebagai sumber fukosantin. Phaeodactylum sp. bisa menghasilkan 15,42-16,51 mg/g dw ketika dikultur dengan intensitas cahaya 2.500 Ix (Kim et al., 2012). Chaetoceros calsitrans juga termasuk salah satu diatom yang biasa dibudidayakan. Chaetoceros sp. mampu tumbuh optimum pada pemberian cahaya 1000 lux, mencapai kepadatan sel maksimum pada 7 hari (Pal et al., 2013) dan produksi fukosantin akan meningkat pada saat memasuki fase stasioner (Wang et al., 2018). Hasil penelitian sebelumnya mengungkapkan bahwa dalam ekstrak metanol C. calcitrans (hasil kultur pada 150 umol $\mathrm{m}^{2} / \mathrm{s}$ ) terkandung karotenoid sebesar $4,46 \pm 0,36 \mathrm{mg} / \mathrm{g} \mathrm{dw}$, dan 2,08 $\pm 0,03 \mathrm{mg} / \mathrm{g}$ $d w$ berupa fukosantin (Foo et al., 2015), bahkan karotenoid bisa mencapai 6,13 $\pm 0,25$ $\mathrm{mg} / \mathrm{g} \mathrm{dw}$, dan $5,13 \pm 0,19 \mathrm{mg} / \mathrm{g} \mathrm{dw}$ berupa fukosantin (Azizan et al., 2018). Penelitian ini bertujuan untuk mengoptimasi kultur $C$. calcitrans dengan perlakuan pemberian intensitas cahaya yang berbeda untuk meningkatkan produksi fukosantin.

\section{MATERI DAN METODE}

Penanaman mikroalga dilakukan menggunakan akuarium $50 \mathrm{~cm} \times 50 \mathrm{~cm} \times 50$ $\mathrm{cm}$ berisi media kultur 60 liter. Masing-masing akuarium diletakkan pada tempat bersekat untuk mengatur intensitas cahaya. Perlakuan intensitasnya (Iux): 1000, 1500, 2000, 2500 dengan 2 kali ulangan. Desain penelitian menggunakan Rancangan Acak Lengkap (RAL). Periode pencahayaan menggunakan 12 jam terang : 12 jam gelap. Sumber cahaya menggunakan lampu TL (Tube Lamp) 18 watt (Philip; $59 \mathrm{~V} ; 1015 \mathrm{Im}$ ) dan 20 watt ( General Electric; 50 V; $870 \mathrm{~lm}$ ). Ketepatan pengukuran intensitas cahaya diatur berdasar jarak lampu yang terpasang di atas akuarium dan dipastikan dengan instrumen luxmeter. Perhitungan intensitas cahaya berdasar rumus Schiler (1992).

Kualitas air dijaga agar mikroalga dapat tumbuh dengan normal. Suhu diatur pada kisaran $25-27 \circ \mathrm{C}$, salinitas $32-33 \%$, $\mathrm{pH}$ 88,5 , dan DO 7-9 mg/g. Setiap akuarium kultur diberi 2 aerator di bagian tengah, dipasang dengan posisi menggantung $2 \mathrm{~cm}$ dari dasarnya. Nutrien yang ditambahkan terdiri dari 3 macam, pupuk diatom (komposisi: $\mathrm{NaH}_{2} \mathrm{PO}_{4} 5 \mathrm{~g}+\mathrm{KNO}_{3} 75 \mathrm{~g}+\mathrm{Na}_{2}$ EDTA $5 \mathrm{~g}+$ $\mathrm{FeCl}_{3} 3,15 \mathrm{~g}$ dalam $1 \mathrm{~L}$ akuades), vitamin (komposisi: $\mathrm{B}_{1} 100 \mathrm{mg}$ dan $\mathrm{B}_{12} 5 \mathrm{mg}$ dalam $1 \mathrm{~L}$ akuades), dan silikat $30 \mathrm{~g} / \mathrm{L}$. Masing-masing diberikan dengan takaran $1 \mathrm{~mL} / \mathrm{L}$ media kultur (BPBAP, 2017). Setelah media kultur siap, dilakukan proses inokulasi. Kepadatan awal $3 \times 10^{6} \mathrm{sel} / \mathrm{mL}$ dan lama kultur 14 hari (Sureshkumar et al., 2014; Foo et al., 2015). Penghitungan kepadatan sel menggunakan haemocytometer setiap 24 jam (jam 09.00 WIB). Pemanenan menggunakan metode flokulasi dengan penambahan aluminium sulfat $\left(\mathrm{Al}_{2}\left(\mathrm{SO}_{4}\right)_{3}\right)$, dosisnya $0,2 \mathrm{~g} / \mathrm{L}$. Biomassa diendapkan selama 12 jam dan disaring menggunakan kain dengan meshsize 400 mikron (Hidayati et al., 2015). Sampel dikeringkan pada suhu $\pm 40^{\circ} \mathrm{C}$ selama 24 jam.

Klorofil a dan fukosantin diekstraksi menggunakan etanol p.a (Merck) berdasar metode maserasi. Sebanyak 0,1 g biomassa kering dimaserasi dengan $10 \mathrm{~mL}$ pelarut (1:100 b/v) pada suhu kamar selama 24 jam dalam kondisi gelap. Filtrat dipisahkan setelah proses sentrifugasi $3000 \mathrm{rpm}$ selama 5 menit dan dilakukan penyaringan dengan Whatman no. 42.

Penentuan konsentrasi pigmen (klorofil a dan fukosantin) berdasar metode Spektrofotometri menggunakan Spektrofotometer UV-Vis (Optima SP.3000 Plus). Absorbansi diukur pada panjang gelombang 445, 632, 649, 663, 665, dan 696 $\mathrm{nm}$. Penghitungan kadar klorofil a menurut Ritchie (2008) dan fukosantin menurut Wang et al., (2018).

Data dianalis menggunakan Anova satu arah dengan selang kepercayaan $95 \%$. Jika berbeda nyata, dilanjutkan dengan uji BNT. Besar pengaruh variabel perbedaan intensitas cahaya terhadap produksi fukosantin diestimasi menggunakan regresi linier.

\section{HASIL DAN PEMBAHASAN}

Pemanenen mikroalga dilakukan pada saat fase stasioner, yaitu 2 hari setelah puncak fase eksponensial. Masing-masing perlakuan intensitas cahaya menghasilkan 
respon puncak pertumbuhan yang berbeda. Peningkatan intensitas menyebabkan kemunduran tercapainya puncak kepadatan sel, sehingga waktu panennya lebih lama. Efek positifnya, meskipun waktu panennya relatif lama, tetapi kepadatannya juga lebih tinggi (terlihat dalam Gambar 1). Kepadatan tertinggi dicapai pada akuarium yang diberi intensitas cahaya $2.500 \mathrm{~lx}$, yaitu mencapai $54,00 \pm 4,00 \times 10^{5} \mathrm{sel} / \mathrm{mL}$ dengan lama kultur 12 hari. Perbedaan pemberian intensitas cahaya berpengaruh nyata terhadap kepadatan sel $(p=0,01)$.

Tekanan peningkatan/penurunan intensitas cahaya tidak akan menghasilkan respon fisiologis dan biokimia yang sama terhadap spesies mikroalga berbeda. Chaetoceros calcitrans termasuk yang mudah beradaptasi dan memberikan respon positif pada kondisi intensitas cahaya tinggi (Zhang et al., 2017). Respon peningkatan intensitas cahaya sampai 2.500 Ix tidak ditanggapi dengan kenaikan berat biomassanya, tetapi dengan peningkatan produksi pigmennya, baik klorofil a maupun fukosantinnya. Seperti diketahui, fungsi pigmen terutama karotenoid, adalah sebagai pelindung sel saat terkena cahaya dengan intensitas tinggi. Intensitas cahaya berpengaruh nyata terhadap kadar klorofil a $(p=0,00)$ dan fukosantin $(p=0,01)$, sekaligus produksi maupun produktivitas fukosantin $(p=0.01)$ yang diperoleh dari total biomassanya (seperti tersaji pada Gambar 2 dan 3).
Fukosantin adalah karotenoid polar, terdapat beberpa gugus fungsi dalam struktur kimianya, berupa : alkohol, alkana, alkena, ester, metil, dan alkena aromatik (Renhoran et al., 2017). Ełanol merupakan pelarut terbaik untuk mengekstrak fukosantin dan bisa dilakukan pada suhu ruang (Kim ef al., 2012). Pelarut lain juga biasa digunakan, yaitu: metanol, aseton, kloroform dalam bentuk murni maupun dengan penambahan akuades. Potensi antioksidannya berkorelasi positif terhadap kadar karotenoidnya, yang didominasi oleh fikosantin (Foo et al., 2017).

$$
\text { Karotenoid dari C. calcitrans }
$$
berkorelasi kuat terhadap aktivitas penangkalan radikal bebas 2,2-diphenyl-1picrylhydrazyl (DPPH) dan penghambatan nitrat oksida (NO). Produksi senyawa NO oleh sel makhluk hidup dipicu oleh oksidative stress (Azizan et al., 2018). Keunggulan pigmen tersebut menjadi alasan penting untuk memanfaatkannya sebagai nutrisi pangan sumber antioksidan alamiah.

Pengaruh intensitas cahaya terhadap produksi fukosantin C. calcitrans pada kisaran 1.000-2.500 Ix sangat signifikan $(p=0,01)$. Korelasi positif antara 2 variabel tersebut juga sangat tinggi $(r=0,96)$. Produksi fukosantin ternyata juga berhubungan erat dengan kadar klorofil a mikroalga $(r=0,81)$. Kenaikan kadar klorofil C. calcitrans seiring dengan kenaikan kadar fukosantin. Berdasar argumentasi Azizan et al. (2018), pigmen fotosintesis dalam diatom terbagi menjadi 2 kategori, klorofil dan karotenoid. Senyawa

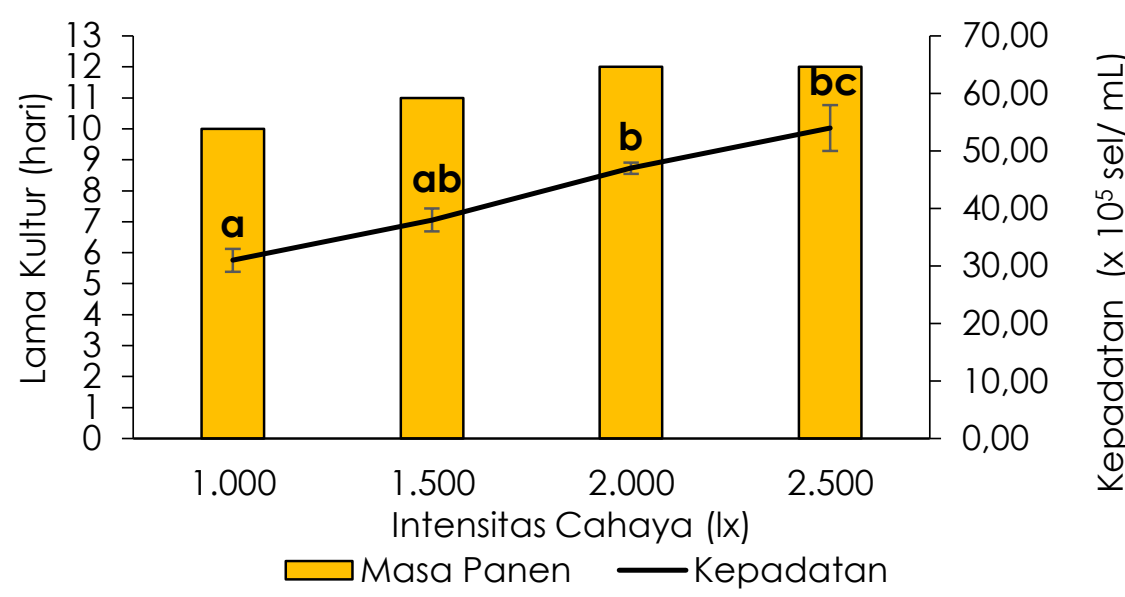

Gambar 1. Pengaruh Perlakuan Intensitas Cahaya Terhadap Kepadatan Sel C. calcitrans $(a=0,05)$ 


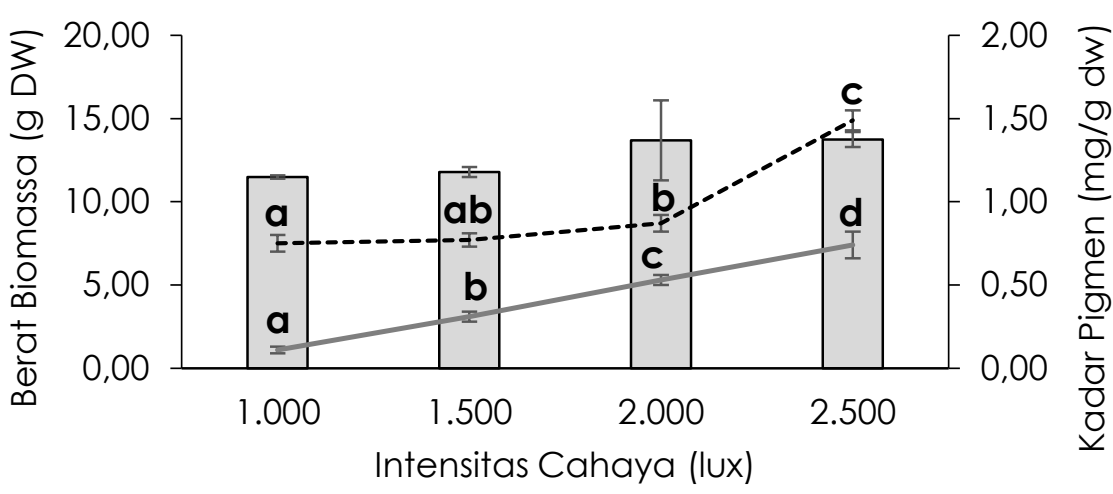

$\square$ Biomassa ------Klorofil a —ukosantin

Gambar 2. Pengaruh Perlakuan Intensitas Cahaya Terhadap Biomassa dan Kadar Pigmen C. calcitrans $(a=0,05)$

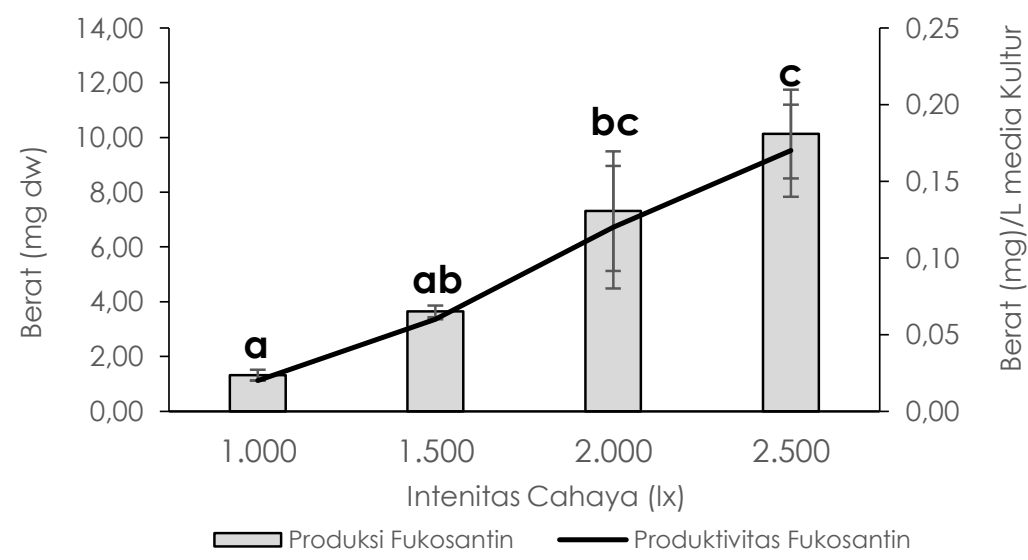

Gambar 3. Pengaruh Perlakuan Intensitas Cahaya Terhadap Produksi dan Produktivitas Fukosantin C. calcitrans $(a=0,05)$

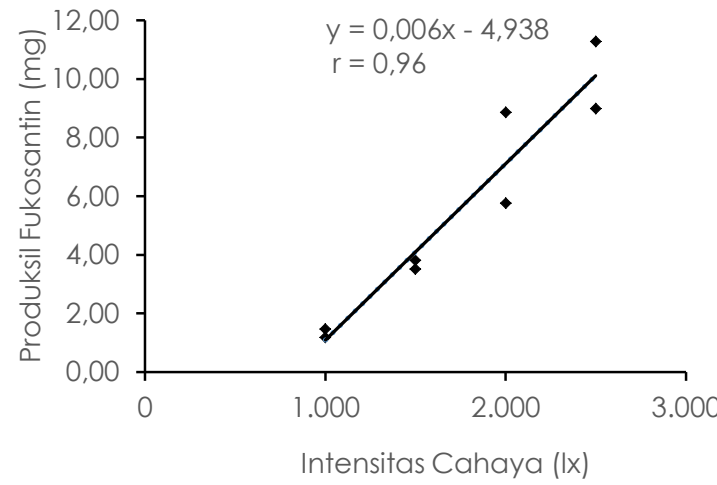

(a)

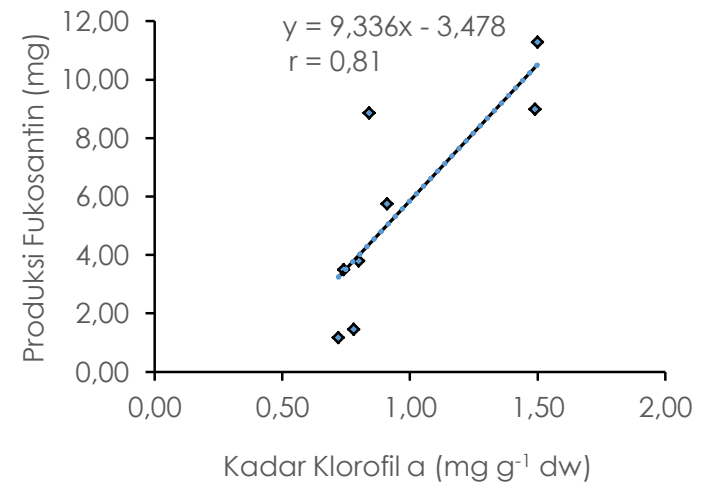

(b)

Gambar 4. Korelasi Intensitas Cahaya (a) dan Kadar Klorofil a (b) Terhadap Produksi Fukosantin C. calcitrans.

yang berperan dalam biosintesisnya adalah geranyl-geranyl diphosphate (GPP) yang diderivasi menjadi geranyl-geranyl pyrophosphate (GGPP). Senyawa GGPP bisa digunakan untuk biosintesis klorofil dan karotenoid berupa likopen. Selanjutnya, 
likopen dipakai untuk biosintesis fukosantin oleh C. calcitrans. Perkusor GPP sendiri adalah asam piruvat dan asetil ko-a, senyawa antara dalam reaksi glikolisis. Asam piruvat dan asetil ko-a adalah perkusor yang banyak terlibat dalam biosintesis metabolit primer dan sekunder. Berdasar asumsi tersebut, glukosa hasil fotosintesis dalam penelitian ini lebih banyak digunakan untuk biosintesis fukosantin dibanding pembentukan biomassanya.

Klorofil berperan dalam proses fotosintesis yang akan menghasilkan glukosa $\left(\mathrm{C}_{6} \mathrm{H}_{12} \mathrm{O}_{6}\right)$. Glukosa akan digunakan oleh berbagai jalur biosintesis, baik metabolisme primer berupa penyusunan biomassa (karbohidrat, protein, lipid) maupun metabolisme sekunder, termasuk pembentukan pigmen. Kadar klorofil a dan fukosantin pada C. calcitrans yang dikultur menggunakan intensitas cahaya $2.500 \mathrm{Ix}$ adalah yang tertinggi di antara yang lain, dapat diasumsikan bahwa fotosintesis berjalan paling baik. Fungsi klorofil a (dibantu c sebagai pigmen asesoris) adalah menangkap energi matahari berupa foton, menggunakannya untuk energi reaksi terang (fotolisis). Hasil reaksi terang berupa senyawa kaya energi (ATP dan NADPH) nantinya akan dipakai untuk menggerakkan reaksi gelap (siklus Calvin), yaitu memfiksasi (asimilasi) $\mathrm{CO}_{2}$ menjadi glukosa. Saat fase stasioner, glukosa tidak digunakan untuk peningkatan produksi metabolit primer, terbukti tidak ada peningkatan berat biomassanya. Peningkatan terjadi pada kadar pigmen, baik klorofil a maupun fukosantinnya.

Hasil penelitian ini membuktikan, bahwa peningkatan intensitas cahaya bisa menaikkan produksi fukosantin. Pemberian intensitas cahaya 2.500 lx menghasilkan produksi fukosantin tertinggi, yaitu sebesar $10,13 \pm 1,62 \mathrm{mg} d \mathrm{w}$ dengan produktivitas sebesar 0,17 $\pm 0,03 \mathrm{mg} / \mathrm{L}$ media kultur. Produksi lebih rendah dihasilkan oleh kultur dengan intensitas $2.000 \mathrm{IX}$, disusul $1.500 \mathrm{~lx}$ dan terendah pada $1.000 \mathrm{~lx}$, secara berurutan menghasilkan $7,31 \pm 2,19,3,65 \pm 0,21$ dan $1,32 \pm 0,20 \mathrm{mg} d w$. Penelitian ini menghasilkan kadar fukosantin tertinggi sebesar $0,17 \mathrm{mg} / \mathrm{g}$

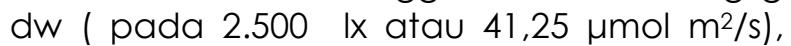
masih lebih rendah dari penelitian sebelumnya. Foo et al. (2015) mengkultur pada $150 \mu \mathrm{mol} \mathrm{m}^{2} / \mathrm{s}$, kadar fukosantinnya sebesar 2,08 $\pm 0,03 \mathrm{mg} / \mathrm{g} \mathrm{dw}$, bahkan hasil kultur dari Azizan et al. (2018) mengandung $5,13 \pm 0,19 \mathrm{mg} / \mathrm{g} \mathrm{dw}$ fukosantin. Peningkatan intensitas cahaya masih bisa ditingkatkan guna memacu produksi fukosantin. Berdasar penelitian Raghavan \& Haridevi (2008), C. calcitrans masih mampu hidup pada intensitas cahaya sampai $500 \mu \mathrm{mol} \mathrm{m} 2 / \mathrm{s}$ atau $30.303,03 \mathrm{~lx}$.

\section{KESIMPULAN}

Peningkatan intensitas cahaya sampai 2.500 Ix pada kultur C. calcitrans skala medium (60 L) dapat meningkatkan produksi fukosantinnya. Perlakuan intensitas cahaya tidak berpengaruh nyata terhadap berat biomassa $(p=0,06)$, tetapi sangat berpengaruh nyata terhadap kepadatan sel $(p=0,01)$, kadar klorofil $(p=0,00)$, dan produksi fukosantin $(p=0,01)$. Pemberian intensitas cahaya 2.500 Ix menghasilkan produksi fukosantin tertinggi, yaitu sebesar 10,13 $\pm 1,62$ $\mathrm{mg} d \mathrm{~d}$ dengan produktivitas sebesar $0,17 \pm 0,03 \mathrm{mg} / \mathrm{g}$ media kultur. Kenaikan intensitas cahaya berkorelasi positif dengan kenaikan produksi fukosantin dengan persamaan regresi $y=0,006 x-4,938(r=$ $0,96)$.

\section{DAFTAR PUSTAKA}

Akbarnejad, M., H. R. Islami., M. J. Babeli., M.S. Mehrgan, \& Y. Filizadeh . 2017. Effect of Light and Nitrogen Concentration on the Growth and Lipid Content of Marine Diatom, Chaetoceros calcitrans, Iranian J. Fish. Sci., 2017:1-9. doi: 10.22092/ijfs. 2018.117035

Azizan, A., Safwan, M., Bustamam, A., Maulidiani, M., Shaari, K.,. Ismail, I.S., Nagao, N. \& Abas, F. 2018. Metabolite Profiling of the Microalgal Diatom Chaetoceros calcitrans and Correlation with Antioxidant and Nitric Oxide Inhibitory Activities. Mar. Drugs, 16(154): 1-19. doi: 10.3390/md16050 154

Barkia, I., \& Saari, N. 2019. Microalgae for High-Value Products Towards Human Health and Nutrition, Mar. Drugs, 17(304):1-29. doi: 10.3390/md 17050304

Balai Perikanan Budidaya Air Payau (BPBAP) Situbondo. 2017. Petunjuk teknis Produksi phytoplankton. Dirjen Kelautan Perikanan 
Budidaya, Kementrian Kelautan Perikanan, Jakarta.

Chilmawati, D. \& Suminto. 2016. The Effect of Different Diet of Phytoplankton Cells on Growth Performance of Copepod, Oithona sp. in Semi-Mass Culture. Aqua. Proc., $\quad 7: 39-45$. doi: 10.1016/j.aq pro.2016.07.005.

Cycloptics. 2019. PPFD Conversion Guide. https://www.cycloptics.com/sites/default /files/Greenbeams\%20PPFD\%20Conversio n\%20Tables_0.pdf (diakses pada 8 Agst 2019).

Foo, S.C., Yusoff, F.M., Ismail, M., Basri, M., Mun, N. \& Khong, H. 2015. Efficient Solvent Extraction of Antioxidant-Rich Extract from a Tropical Diatom, Chaetoceros calcitrans (Paulsen) Takano 1968. Asian Pacific J. Trop. Biomed., 5(10):834-840. doi: 10.1016/ j.apjtb.2015.06.003

Foo, S.C., Yusoff, F.M., Ismail, M., Basri, M., Yau, S.K., Khong, N.M.H., Chan, K.W. \& Ebrahimi, M. 2017. Antioxidant Capacities of Fucoxanthin-Producing Algae as Influenced by Their Carotenoid and Phenolic Contents. J. Biotechnol., 241: 175-183. doi: $\quad 10.10$ 16/j.jbiotec.2016.11.026

Gatamaneni, G.L., Orsat, V. \& Lefsrud, M. 2018. Factors Affecting Growth of Various Microalgal Species. Environ. Eng. Sci. 35(10):1037-1048.

Hemaiswarya, S., Raja, R., Kumar, R.R., Ganesan, V., \& Anbazhagan, C. 2011. Microalgae: A Sustainable Feed Source for Aquaculture. World J. Microbiol. Biotechnol., 27(8):1737-1746.

Heo, S.J., Yoon, W.J., Kim, K.N., Ahn, G.N., Kang, S.M., Kang, D.H., Affan, A., Oh C., Jung, W.K. \& Jeon, Y.J. 2010. Evaluation of Anti-inflammatory Effect of Fucoxanthin Isolated from Brown Algae in Lipopolysaccharide-stimulated RAW 264.7 Macrophages. Food Chem. Toxicol., 48:2045-2051.

Hidayati, S., Nawansih, O. \& Febiana, V. 2015. Teknik Pemanenan Mikroalga Nannochloropsis sp. yang dikultur dalam media limbah cair karet remah dengan Flokulan Alumunium Sulfat. J. Teknol. Industri Hasil Pertanian, 20(2):1 -7.

Hu, J., Nagarajan, D., Zhang, Q., Chang, J.S. \& Lee, D.J. 2018. Heterotrophic
Cultivation of Microalgae for Pigment Production: A Review. Biotechnol. Adv., 36(1):54-67.

Kim, S.M., Jung, Y. \& Kwon, O. 2012. A Potential Commercial Source of Fucoxanthin Extracted from the Microalga Phaeodactylum tricornutum a Potential Commercial Source of Fucoxanthin Extracted from the Microalga Phaeodactylum tricornutum. Appl. Biochem. Biotechnol., 166:18431855. doi: 10.10 07/s 12010-012-9602-2

Krichnavaruk, S., Loataweesup, W., Powtongsook, S. \& Pavasant, P. 2005. Effect of Light and Nitrogen Concentration on the Growth and Lipid Content of Marine Diatom, Chaetoceros calcitrans. Chem. Eng. J., 105:91-98.

Kumar, S.R., Hosokawa, M. \& Miyashita, K.. 2013. Fucoxanthin: A Marine Carotenoid Exerting Anti-Cancer Effects by Affecting Multiple Mechanisms. Mar. Drugs, 11:5130-5147. doi : $10.3390 / \mathrm{md} 11125130$

Kwangdinata, R., Raya, I. \& Zakir, M.. 2014. Production of Biodiesel from Lipid of Phytoplankton Chaetoceros calcitrans hrough Ultrasonic Method. Sci. World J., 2014:1-5.

Maeda, H., Hosokawa, M. \& Sashima, T. 2017. Anti-obesity and Anti-diabetic Effects of Fucoxanthin on Diet-induced Obesity Conditions in a Murine Model. Mar. Drugs, 2:897-902 doi: $10.3892 / \mathrm{mmr}$

Nursid, M., Wikanta, T. \& Susilowati, R. 2014. Aktivitas Antioksidan, Sitotoksisitas dan Kandungan Fukosantin Ekstrak Rumput Laut Coklat dari Pantai Binuangeun, Banten. J. Pascapan. Bioteknol. Kel. Perikan., 8(1):73-84. doi: 10.15578/jpbkp. v8il.55

Pal, S.W., Singh, N.K. \& Azam, K. 2013. Oceanography and Marine Research Evaluation of Relationship between Light Intensity (LU ) and Growth of Chaetoceros muelleri, Oceanograp., 1 (3):1-4. doi: 10.4172/2332-2632.100 0111

Raghavan, G. \& Haridevi, C.K. 2008. Growth and Proximate Composition of the Chaetoceros calcitrans $f$. pumilus Under Different Temperature, Salinity and Carbon Dioxide Levels. Aquaculture Research, 39: 1053-1058. doi: $10.1111 / j .1365-2109.2008 .01964 . x$

Renhoran, W., Noviendri, D., Setyaningsih, I. \& 
Uju. 2017. Ekstraksi dan Purifikasi Fukosantin dari Sargassum sp. sebagai Anti-Acne. J. Pengolahan Hasil Perikan. Ind., 20(2):370-379. doi : 10.17844/jphpi. v20i2.18105

Ritchie, R.J. 2008. Total Chlorophylls in Natural Assemblages of Photosynthetic Organisms Using Acetone, Methanol, or Ethanol Solvents. Photosynthetica, 46 (1):115-126. doi: 10.1007/s1 1099-008-00197

Schiler, M. 1992. Simplified Design of Building Lighting, John Wiley and Sons inc. New York.

Sirin, S., Clavero, E. \& Salvado, J. 2015. Efficient Harvesting of Chaetoceros calcitrans for Biodiesel Production. Environ. Technol., 36(15):1902-1912

Sureshkumar, S., Jasmin. B., Rahiman, K.M.M. \& Mohammed, A.A.H. 2014. Growth Enhancement of Microalgae Chaetoceros calcitrans and
Nannochloropsis oculata Using Selected Bacterial Strains. Int. J. Curr. Microbiol. App. Sci., 3(4): 352-359.

Wang, L., Fan, Y., Parsons, R.L. , Hu, G. \& Zhang, P. 2018. A Rapid Method for the Determination of Fucoxanthin in Diatom. Mar. Drugs, 16(33):1-13. doi: 10.3390/md 16010033

Ye, Z.W., Jiang, J.G. \& WU, G.H. 2008. Biosynthesis and Regulation of Carotenoids in Dunaliella: Progresses and Prospects. Biotechnolog. Adv., 26(4): 352360. doi: 10.1016/j.biotechadv. 2008.03. 004

Zhang, R., Kong, Z., Chen, S., Ran, Z., Ye, M. XU, J., Zhoub, C., Liaoa, K., Cao, J. \& Yan, $X$. 2017. The Comparative Study for Physiological and Biochemical Mechanisms of Thalassiosira pseudonana and Chaetoceros calcitrans in Response to Di fferent Light Intensities. Algal Res., 27: 89-98. doi: 10.1016/j.algal.2017.08.0 26 